by Stanley C. Finney

\title{
Formal definition of the Quaternary System/Period and redefinition of the Pleistocene Series/Epoch
}

Chair - International Commission on Stratigraphy (IUGS); Department of Geological Sciences, California State University at Long Beach, Long Beach CA 90840, USA. E-mail: scfinney@cslb.edu

The base of the Quaternary System is formally defined for the first time at the base of the Gelasian Stage as defined by the Global Boundary-Stratotype Section and Point (GSSP) at San Nicola, Sicily, Italy; the Pleistocene Series is extended downwards to coincide with the base the Gelasian Stage; accordingly, the Gelasian Stage is transferred from the Pliocene Series and Neogene System to the Pleistocene Series and Quaternary System. Ratification by the Executive Committee of the International Union of Geological Sciences (IUGS) of these recommendations from the International Commission on Stratigraphy (ICS) followed established procedures of extended, open discussion and deliberation of submitted proposals, and formal voting by the relevant ICS Subcommissions, the ICS Voting Membership, and the IUGS EC. They are now established as global standards.

\section{Introduction}

On 29 June 2009, the Executive Committee of the International Union of Geological Sciences (IUGS) ratified the recommendation from the International Commission on Stratigraphy (ICS) for formally defining, for the first time, the base of the Quaternary System at the base of the Gelasian Stage as defined by the Global Boundary Stratotype Section and Point (GSSP) at San Nicola, Sicily, Italy and for lowering the base of the Pleistocene Series to also coincide with the base of the Gelasian Stage. The Pleistocene Series was thus extended downwards to include the Gelasian Stage, which previously was the uppermost stage of the Pliocene Series and Neogene System. Accordingly, the beginning of the Quaternary Period and Pleistocene Epoch are now contemporaneous with the beginning of the Gelasian Age. These decisions result from a long, complicated, and, at times, contentious process over several years. This report describes the process by which the decisions were reached by ICS and IUGS. In an accompanying paper (Gibbard and Head, this volume), the scientific rationale for the decisions is presented.

Efforts to formally define the lower boundary for the Quaternary and thus the Pleistocene began in 1948, and resulted in the ratification in 1985 by ICS and IUGS of the Vrica GSSP as the boundary stratotype for the Pleistocene Series and thus the Pliocene-Pleistocene boundary
(Aguirre and Pasini, 1985). However, many Quaternary geoscientists did not agree with the chosen boundary level, and, following ICS and IUGS ratification of the GSSP for the base of the Gelasian Stage in 1996, they launched an effort to lower the boundary level to coincide with the base of the Gelasian Stage. They preferred this lower level because, they maintained, it more closely correlates with stratigraphic signals for the onset of global cooling, which they considered to mark the beginning of the Quaternary Period and Pleistocene Epoch (see, for example, Partridge, 1997). A joint Quaternary-Neogene task group was established by ICS in 1998 to consider the proposal to lower the boundary, but the proposal failed to receive the statutory number of votes $(>60 \%)$ for recommendation. As a consequence, in January 1999 the IUGS Executive Committee reaffirmed the Vrica GSSP as defining the base of the Pleistocene and Quaternary (see Remane, 2000), such that a 10-year moratorium precluded further consideration of its redefinition.

\section{The Quaternary on ICS Charts}

Whenever shown in textbooks and on stratigraphic charts, time scales, and correlation charts, the Quaternary consisted of the Pleistocene and Holocene. Accordingly, with regard to the Vrica GSSP, the establishment of an internationally accepted Pleistocene boundary-stratotype is, by definition, the Quaternary boundary as well (cf. van Couvering, 1997: xv). Thus, the global stratigraphic chart produced by the ICS chair and secretary-general in 1989 (Cowie and Bassett, 1989) showed the Quaternary as a period composed of the Pleistocene and Holocene epochs and following upon the Neogene. So, too, did the International Chronostratigraphic Chart produced by the ICS in 2000 (Remane, 2000), printed by UNESCO, bearing the logos of UNESCO and IUGS, and distributed in registration packets at the 31st International Geological Congress in Rio de Janeiro, Brazil. Accordingly, the publication of Geologic Time Scale 2004 (Gradstein et al., 2004a) with the Chair and the Secretary-General of ICS (Felix Gradstein and James Ogg, respectively) as the first two of its three authors, with the Quaternary lacking as a formal chronostratigraphic unit, and with the Neogene extending to the present and including the Pleistocene and Holocene, was unexpected. The time-scale included in this publication bore the logos of ICS and IUGS, the statement "Copyright (C) 2004 International Commission on Stratigraphy", and press releases stated that it was "ratified by the International Commission on Stratigraphy." The same chart also was figured in Gradstein and Ogg (2004), Gradstein et al. (2004b) and Ogg (2004) in articles published immediately before the $32^{\text {nd }}$ IGC in 
Florence, Italy. The abstract of Gradstein et al. (2004b) stated that the accompanying International Stratigraphic Chart was "issued under [the] auspices of the International Commission on Stratigraphy (ICS)".

A chart without the Quaternary had not been, however, considered by the ICS Bureau or within the ICS during the period of 1996 to 2004 when I served as Chair of the Ordovician Subcommission (19962004), as $2^{\text {nd }}$ Vice-chair of ICS (2000-2004), and as sole Vice-chair of ICS (2004-2008). Moreover, the Neogene had never been shown previously on any ICS-produced chart as including the Pleistocene and Holocene, and the work of the Neogene Subcommission had been always limited to the Miocene and Pliocene series. Thus, extending the Neogene to include the Pleistocene and Holocene was certainly a matter that, following ICS Statutes, needed to be considered by the entire ICS Voting Membership (the ICS Executive and chairs of all subcommissions) and approved only after receiving a supermajority vote $(>60 \%)$ followed by ratification by the IUGS Executive Committee. Thus, omission of all formal procedures and lack of prior notice and consultation resulted in an unacceptable situation for stratigraphers and, especially, Quaternary researchers (e.g., Pillans and Naish, 2004; Gibbard et al., 2005; Bowen and Gibbard, 2007). These circumstances were strongly exposed at the $32^{\text {nd }}$ International Geologic Congress in Florence, and a census of Quaternary scientists and organizations worldwide, organized by INQUA, overwhelming rejected the omission of the Quaternary from the stratigraphic charts.

\section{ICS Addresses the Controversy}

To deal with the controversy, an ICS-INQUA Task Group was appointed by ICS Chair Gradstein in 2004 with the objective of formulating a single proposal on defining the Quaternary. The Task Group Recommendation, dated June 10, 2005, was as follows: (1) That the Quaternary is to be ratified as a formal chronostratigraphic/ geochronologic subdivision of the Cenozoic Erathem/Era. (2) That the base of the Quaternary is to be defined by the GSSP of the Gelasian Stage. (3) That the Quaternary will have the rank of either: (a) System/ Period and will be at the top of the Neogene System/Period, with its lower boundary marking the top of a shortened Neogene, or (b) Suberathem/Sub-era and will be correlative with the upper part of the Neogene System/Period.

On August 31, 2005, the INQUA Executive Committee considered the Report of the Task Group, and issued a statement, which was sent to the ICS Chair, favouring the status of Quaternary as a Period. Meanwhile, the Task Group recommendation was presented to the ICS Voting Membership at its workshop in Leuven, Belgium in September 2005. A formal ballot taken by e-mail led to ICS approval of items 1, 2, and 3b, i.e. that the Quaternary have the rank of Sub-erathem/Sub-era with its base coincident with the base of the Gelasian Stage. The vote of the ballots was 12 'yes', 5 'no', and 1 'abstain'.

The ICS recommendations were submitted to the IUGS EC and INQUA EC on October 3, 2005. INQUA's answer was that it would take them several months to canvass their membership and determine whether the ICS proposal was acceptable. In November 2005, the ICS Chair and Secretary (F. Gradstein and J. Ogg) submitted a paper to Episodes summarizing the decision taken by ICS. Publication of this article was postponed as the ICS proposal was still under study by the IUGS EC. Meanwhile the ICS proposal was published in the journal Stratigraphy (2005, vol. 2: 191-192).

On August 2006 the IUGS Executive Committee rejected the ICS recommendations because they were not in agreement with the long-standing protocol and procedural principles that have been accepted by the international geological community, and established by ICS itself in the International Stratigraphic Guide (Salvador, 1994) and the "Revised Guidelines for the Establishment of Global Chronostratigraphic Standards of the ICS" (Remane et al., 1996). The IUGS EC noted: (a) that the lower boundaries of chronostratigraphic units of higher rank (series, systems, etc.) are automatically defined by the base of their lowermost stage. In other words: the lower boundary of a system is always also a series and a stage boundary; (b) that a unit of lower rank cannot be part of two units of higher rank, i.e. a system cannot be part of two erathems, a series cannot be part of two systems, and a stage cannot be part of two series; (c) that restraint is recommended in creating new orders of chronostratigraphic units, as sub-erathem, sub-system, sub-series and sub-stage. Thus, the IUGS EC concluded that the principle of hierarchy, inherent in the International Chronostratigraphic Scale, is clearly violated if a sub-erathem/sub-era boundary does not coincide with either a system/period or series/epoch boundary. The decision of the IUGS Executive Committee stated "it is inappropriate to detach the beginning of the Quaternary from the beginning of the Pleistocene and to propose the Pliocene to overlap the Tertiary and Quaternary or the Quaternary to include parts of the Pleistocene and Pliocene."

At the beginning of 2007, the IUGS EC directed ICS to continue its dialogue with INQUA, to immediately readdress the issue of the Quaternary following the principles, rules, and working agreements agreed upon by all parties, and to postpone publishing any change on this matter unless it has been previously approved by the IUGS EC. The IUGS EC also affirmed that "the Quaternary remains as depicted in the International Stratigraphic Chart published by IUGS in 2000" (Remane, 2000).

In April 2007, ICS Secretary-General James Ogg circulated a new ballot on the Quaternary to the ICS Voting Membership. The recommendations on the ballot read as follows: (1) The Quaternary is a full formal chronostratigraphic unit, the appropriate status for which is the System. The underlying System is the Neogene. (2) The base of the Quaternary is placed at the current base of GSSP Gelasian Stage (currently in the Pliocene) at the base of Marine Isotope Stage (MIS) 103, which was calibrated to an age of $\sim 2.6 \mathrm{Ma}$. (3) The base of the Pleistocene Series is lowered to coincide with that of the Quaternary System boundary (= Gelasian Stage GSSP). (4) The GSSP at Vrica, Italy (the former Plio-Pleistocene boundary), is retained as the base of the Calabrian Stage, the second stage of the revised Pleistocene Series. The ballot was distributed without any serious attempt at open discussion or input. The recommendations were approved with a vote of 14 'yes', 2 'no', and 1 'abstain' (one member did not vote), and they were forwarded to the IUGS EC.

The recommendation to ratify the Quaternary as a formal system/ period of the international geological scale was approved unanimously by the IUGS EC. However, the IUGS EC did not approve the simultaneous definition of the base of the Quaternary because the ICS recommendation did not follow established protocol for consultation, discussion and voting by the ICS. The IUGS EC declared 
that this next step could not be rushed and should be a key topic for discussion at the $33^{\text {rd }}$ International Geological Congress in Oslo in 2008.

At the $33^{\text {rd }}$ International Geological Congress in Oslo, I began a 4-year term as Chair of the International Commission on Stratigraphy. Having been elected in November 2007, I prepared to face the Quaternary issue by laying out a series of steps that would allow all positions to be presented, discussed, and deliberated and that allowed contributions to the discussions from all who desired to make them whether or not they were ICS Voting Members. These steps were (1) an open discussion session at the Geological Congress in Oslo, (2) submission of formal written proposals to ICS, (3) consideration of the proposals by the Quaternary and Neogene subcommissions, (4) forwarding to ICS of any proposal receiving a majority of "yes" votes from one or the other or both subcommissions, (5) discussion and deliberation of proposals forwarded to ICS from the subcommissions, (6) preparation and distribution of formal ballots for a vote on the proposals, (7) a final round of voting on the single proposal favored by the majority of the ICS Voting Members, and (8) if approved by ICS by a supermajority vote $(>60 \%)$, forwarding of the proposal to the IUGS Executive Committee for ratification.

\section{The open 'public' discussion session at the Oslo Congress}

The discussion session was announced in Science (25 January 2008 issue) and GSA Today (June 2008 issue) as well as on the ICS and Quaternary Subcommission websites; the ICS voting members were instructed to attend, and major proponents of various positions were specifically invited to make presentations. The purpose of the discussion session was to allow all who desired to present their positions, but also to have those positions or specific aspects of them challenged by the session chairs as well as all in attendance. As chair of ICS, I chaired the session and recruited INQUA Past-President John Clague to co-chair it with me. Given that the system/period rank of the Quaternary was approved by ICS and ratified by IUGS in 2007, the primary question to be addressed in the discussion session was the level at which to define the lower boundary of the Quaternary and whether or not the base of the Pleistocene should also coincide with that boundary. The discussion session was held on the evening of 9 August 2008. It was preceded that day by the symposium "Pliocene-Pleistocene correlations and global change" in which many presentations illustrated impressively high-resolution correlations of Quaternary successions worldwide that contained remarkable and varied records of climatic changes. In the evening discussion session, representatives of the 'Quaternary' position argued for definition of the Quaternary at the base of the Gelasian Stage and redefinition of the base-Pleistocene at the same level. Others, here called the 'traditionalists,' argued that in order to preserve stability the definition of the Pleistocene at the Vrica GSSP must not be changed, and that the base-Quaternary should also be defined by the Vrica GSSP. Finally, 'Neogene' proponents argued that the Neogene should be extended upwards to the present, that the Pleistocene remain defined by the Vrica GSSP, and that the rank of the Quaternary be eliminated as a formal unit or that its rank be changed. A summary of the discussion session is posted in archives on the ICS website (www.stratigraphy.org). Following the session, proponents of the 'Quaternary' and 'Neogene' positions were directed to submit formal proposals to ICS if they wished them to be considered further.

\section{Submission of formal proposals and consideration by subcommissions}

On 1 September 2008, Philip Gibbard and Martin Head submitted the formal 'Quaternary' proposal: That the base of the Quaternary System/Period be lowered to the Gelasian Stage GSSP (at 2.588 Ma), and that the base of the Pleistocene Series be lowered to the same position. On 29 September 2008, Frits Hilgen and several co-authors submitted a formal 'Neogene' proposal: That the Cenozoic Era comprises the Paleogene and Neogene Periods and that the Quaternary be a Sub-Period spanning the past $2.6 \mathrm{Myr}$; that the Quaternary is equivalent to the Late Neogene (Gelasian Age), Pleistocene, and Holocene; that the Pliocene/Pleistocene boundary remains at 1.8 as currently defined but the Pliocene Epoch is split into an Early Pliocene and a Late Pliocene in order to maintain hierarchy in the global chronostratigraphic scale. The full text of these proposals and supplementary documents are archived at www.stratigraphy.org. Upon receipt of these proposals, I forwarded both to the chairs of the Quaternary and Neogene subcommissions (Philip Gibbard and Frits Hilgen, respectively) and directed them to have the voting members of their respective subcommissions discuss, deliberate, and vote on the proposals.

The Quaternary Subcommission voted overwhelmingly to recommend the 'Quaternary' proposal (19 'yes', 1 'no', 0 'abstain') and to reject the 'Neogene' proposal (0 'yes', 18 'no', 2 'abstain'), and the Neogene Subcommission voted overwhelmingly to recommend the 'Neogene' proposal (13 'yes', 3 'no', 1 'abstain') and to reject the 'Quaternary' proposal (2 'yes', 14 'no', 0 'abstain'). Thus, having each been approved by a subcommission, the 'Quaternary' and 'Neogene' proposals were forwarded in December 2008 to ICS for consideration.

\section{Discussion and deliberation of the 'Quaternary' and 'Neogene' proposals by the ICS Voting Membership}

On 29 January 2009, the 'Quaternary' and 'Neogene' proposals were distributed to the ICS Voting Membership, and on 10 February 2009 I initiated a discussion session with all comments and contributions encouraged, submitted by e-mail, distributed immediately to the Voting Membership by e-mail, and also posted on the ICS website. In the letter of instructions, I summarized the history of the controversy since the ratification of the Vrica GSSP in 1985 and specified the present situation with the Quaternary formally ratified as a System/Period following upon the Neogene System/Period and with the base Pleistocene Series/Epoch defined by the Vrica GSSP. I set 10 March 2009 as the date at which the discussion period would end. Discussion was lively and extended. Arguments and counterarguments were submitted by proponents of the various positions, including several who were not ICS Voting Members. All are posted at the ICS website. With the end of the discussion period on 12 March 2009, after the deadline set for the discussion period, I circulated my summary of the three positions before the ICS Voting Membership to all ICS Voting Members, my impressions of each of 
them, the primary justification for each position, and the impact each had for the International Chronostratigraphic Chart/Geologic Time Scale. And, with regard to the impact of the 'Neogene' proposal, I distributed a further clarification on 22 March 2009. Also in the 12 March message to ICS Voting Members, I extended the discussion by ten days to give those who wished an opportunity to respond to my summary comments. During this time, the authors of the 'Neogene' proposal requested that the proposal be restated as a stepwise approach with only the following points being the core of the proposal: the Neogene extended upwards to include the Pleistocene and Holocene, the Cenozoic composed of only the Paleogene and Neogene Periods, and the Pliocene-Pleistocene boundary at 1.8 Ma, and with the question of the rank at which to include the Quaternary in a Cenozoic with only two periods to be addressed at a later date in consultation with the Quaternary community. I did not allow this change. The rank and extent of the Quaternary were essential parts of the 'Neogene' proposal that was submitted, and it had been promoted in several papers published by proponents of the proposal and submitted in support of it (Aubry et al., 2005, 2009; Lourens, 2008). The goal of the process initiated with the open discussion session at the Oslo Congress was a decision on the rank and extent of the Quaternary; it was not to be sidetracked. I had directed the Neogene Subcommission, as well as the Quaternary Subcommission, to consider, discuss, and deliberate the 'Neogene' and 'Quaternary' proposals, and, if the proponents of the 'Neogene' proposal wanted to modify it, that was the time to do so. Furthermore, the IUGS Executive Committee had ratified the Quaternary as a System/Period; thus, proposals submitted to ICS for consideration had to specifically address its rank. To decide, immediately before ballots were to be distributed to the ICS Voting Membership, to change the proposal such that no rank was to be specified for the Quaternary was unacceptable.

\section{The Ballots and Voting}

Voting by the ICS Membership required at least two and possibly three rounds, first to decide among the three positions on the table and then to vote 'yes' or 'no' on the single proposal with the greatest majority vote. Besides the 'Quaternary' and 'Neogene' proposals, a 'Status Quo' proposal was included. It reflected the then existing situation with the Pleistocene Series/Epoch defined by the Vrica GSSP and the Quaternary having the rank of System/Period. If neither the 'Quaternary' proposal nor the 'Neogene' proposal was approved by the ICS Voting Members, then a formal definition of the base of the Quaternary System/Period at the Vrica GSSP would need to be considered. The 'Status Quo' proposal thus read: Pleistocene Series/ Epoch remains defined by Vrica GSSP. The base of the Quaternary System/Period is formally defined also by the Vrica GSSP, corresponding to the base of the Pleistocene Series/Epoch and Calabrian Stage/Age, and serving also as the NeogeneQuaternary boundary. The 'Quaternary' proposal read: Base of Pleistocene Series/Epoch is lowered such that the Pleistocene includes the Gelasian Stage/Age and its base is defined by the Monte San Nicola GSSP, which also defines the base of the Gelasian. In addition, the base of the Quaternary System/Period, and thus the Neogene-Quaternary boundary, is formally defined by Monte San Nicola GSSP and is coincident with the bases of the Pleistocene and Gelasian. With these definitions the Gelasian
Stage/Age is transferred from the Pliocene Series/Epoch to the Pleistocene. The 'Neogene' proposal read: Pleistocene Series/Epoch remains defined by Vrica GSSP. The Pliocene Series/Epoch is split into two series/epochs named Lower/Early Pliocene and Upper/Late Pliocene, with the later composed of the Gelasian Stage/Age and with its base defined by the Monte San Nicola GSSP. The rank of the Quaternary is changed from system/period to subsystem/subperiod; its base is formally defined by the Monte San Nicola GSSP. As a result, the Quaternary is composed of the Upper/Late Pliocene, Pleistocene, and Holocene series/epochs. The Neogene System/Period extends upwards such that it includes the Miocene, Lower/Early Pliocene, Upper/Late Pliocene, Pleistocene, and Holocene series/epochs. The ballot was entitled 'Vote on the rank, extent, definition and/or redefinition of the Quaternary, Pleistocene, Neogene, and Pliocene'. Ballots were distributed by email on 24 March 2009; the deadline for receipt was 23 April 2009 30 days after distribution.

ICS Voting Members were directed to vote 'yes', 'no', or 'abstain' on each of the three proposals with the goal of determining which of the three proposals, even if more than one, were acceptable to a majority of the voters. If two or more were acceptable, a second round of voting would determine which of these proposals was favored by the majority of the voting members. The 'Quaternary' proposal received a supermajority of 'yes' votes (72\%) in the first round, while the 'Neogene' and 'Status Quo' positions failed to reach majorities of 'yes' votes. Voting results, completed and compiled on 22 April 2009, are shown in Table 1.

The second round of voting included only the 'Quaternary' proposal with directions to vote 'yes', 'no', or 'abstain'. Ballots were distributed on 22 April 2009; the deadline for receipt was 22 May 2009. The result of the second round was 16 'yes' votes, 2 'no' votes, and 0 'abstain'. Thus, the 'Quaternary' proposal was

Table 1. Results of First Round Voting on Quaternary-NeogenePleistocene-Pliocene redefinition. All ballots received and votes compiled on 22 April 2009 by S. Finney.

\begin{tabular}{lccc}
\hline Name - position & Status Quo & Quaternary & Neogene \\
\hline Finney - ICS Chair & Abstain & Yes & No \\
Peng - ICS Vice Chair & & & \\
and Cambrian & No & Yes & No \\
Bown - ICS Sec.-Gen. & Yes & No & No \\
Gibbard - Quaternary & No & Yes & No \\
Hilgen - Neogene & No & No & Yes \\
Molina - Paleogene & Abstain & No & Yes \\
Primoli Silva - Cretaceous & Abstain & Yes & No \\
Palfy - Jurassic & No & Yes & No \\
Balini - Triassic & No & Yes & No \\
Henderson - Permian & Yes & Yes & No \\
Richards - Carboniferous & No & Yes & No \\
Becker - Devonian & No & Yes & No \\
Melchin - Silurian & No & Yes & No \\
Harper - Ordovician & No & Yes & No \\
Gehling - Neoproterozoic & No & No & Yes \\
Van Kranendonk - Precambrian & No & No & Abstain \\
Pratt - Strat Classif & No & Yes & No \\
Ogg - Strat Inf. Serv. & No & Yes & No \\
Total Yes & 2 & 13 & 3 \\
$\quad$ No & 13 & 5 & 14 \\
$\quad$ Abstain & 3 & 0 & 1 \\
\hline
\end{tabular}


Table 2. Results of Second-Round Voting; only 'Quaternary' proposal on ballot. All ballots received and votes compiled on 22 May 2009 by S. Finney.

\begin{tabular}{|c|c|c|c|}
\hline Name - position & Yes & No & Abstain \\
\hline Finney - ICS Chair & $\mathrm{X}$ & & \\
\hline Peng - ICS Vice Chair & & & \\
\hline and Cambrian & $\mathrm{X}$ & & \\
\hline Bown - ICS Sec.-Gen. & $\mathrm{X}$ & & \\
\hline Gibbard - Quaternary & $\mathrm{X}$ & & \\
\hline Hilgen - Neogene & & $\mathrm{X}$ & \\
\hline Molina - Paleogene & $\mathrm{X}$ & & \\
\hline Primoli Silva - Cretaceous & $\mathrm{X}$ & & \\
\hline Palfy - Jurassic & $\mathrm{X}$ & & \\
\hline Balini - Triassic & $\mathrm{X}$ & & \\
\hline Henderson - Permian & $\mathrm{X}$ & & \\
\hline Richards - Carboniferous & $\mathrm{X}$ & & \\
\hline Becker - Devonian & $\mathrm{X}$ & & \\
\hline Melchin - Silurian & $\mathrm{X}$ & & \\
\hline Harper - Ordovician & $\mathrm{X}$ & & \\
\hline Gehling - Neoproterozoic & $\mathrm{X}$ & & \\
\hline Van Kranendonk - Precambrian & & $\mathrm{X}$ & \\
\hline Pratt - Strat Classif & $\mathrm{X}$ & & \\
\hline Ogg - Strat Inf. Serv. & $\mathrm{X}$ & & \\
\hline Total & 16 & 2 & 0 \\
\hline
\end{tabular}

overwhelmingly approved with an $89 \%$ of 'yes' votes. Voting results are shown in Table 2.

\section{Ratification by the IUGS Executive Committee}

The 'Quaternary' proposal approved by the ICS Voting Membership was forwarded to the IUGS Executive Committee on 2 June 2009. On 29 June 2009, the IUGS Executive Committee approved the ICS recommendation, thus formally ratifying it. With this ratification, the definition of the Quaternary System/Period and the redefinition of the Pleistocene Series/Epoch are now set as global standards and cannot be considered for revision for ten years, and, even then, only if it can be shown that they are seriously deficient.

\section{The process of setting global standards}

The ICS process from 2008 onwards ran its full course following established procedures. Open discussion was encouraged at each step in the process and both in the subcommissions and among the ICS Voting Membership. All who desired were provided opportunities to present their positions, arguments, and objections, and all positions and supporting arguments were open to challenge. The process was fully transparent. Most importantly, those voting were provided with the extended discussion and deliberation that allowed them to make informed decisions with their votes. They are to be congratulated for their serious consideration of this matter. The proponents of the various positions are also congratulated for the knowledge, expertise and passion that they expressed; this was essential for critical evaluation of the various proposals and the importance of the issues under consideration.

The extensive process of discussion, consideration of formal proposals, and voting at the levels of subcommission and commission and final review and ratification by the IUGS Executive Committee gives legitimacy to these decisions as global standards.

\section{References}

Aguirre, E., and Pasini, G., 1985. The Pliocene-Pleistocene boundary: Episodes, v. 8, pp. 116-120.

Aubry, M-P., Berggren, W.A., Van Couvering, J., McGowran, B., Pillans, B., and Hilgen, F., 2005. Quaternary: status, rank, definition, survival: Episodes, v. 28, pp. 118-120.

Aubry, M-P., Berggren, W.A., Van Couvering, J., McGowran, B., Hilgen, F., Steininger, F., and Lourens, L., 2009. The Neogene and Quaternary: chronostratigraphic compromise or non-overlapping magisterial?: Stratigraphy, v. 6, pp. 1-16.

Bowen, D.Q., and Gibbard, P.L., 2007. The Quaternary is here to stay: Journal of Quaternary Science, v. 22, pp. 3-8.

Cowie, J.W., and Bassett, M.G., (Compilers), 1989. International Union of Geological Sciences 1989 global stratigraphic chart with geochronometric and magnetostratigraphic calibration: Episodes, v. 12, supplement 1 sheet.

Gibbard, P.L., Smith, A.G., Zalasiewicz, J.A., Barry, T.L., Cantrill, D., Coe, A.L., Cope, J.W.C., Gale, A.S., Gregory, F.J., Powell, J.H., Rawson, P.R., Stone, P., and Water, C.N., 2005. What status for the Quaternary?: Boreas, v. 34, pp. 1-6.

Gradstein, F.M., and Ogg, J.G., 2004. Geologic Time Scale 2004 - why, how and where next!: Lethaia, v. 37, pp. 175-181.

Gradstein, F.M., Ogg, J.G., and Smith, A.G., eds., 2004a. A Geologic Time Scale 2004: Cambridge University Press, Cambridge, 589 pp.

Gradstein, F.M., Ogg, J.G., Smith, A.G., Bleeker,W., and Lourens, L.J., 2004 b. A new Geologic Time Scale, with special reference to Precambrian and Neogene: Episodes, v. 27, pp. 83-100.

Lourens, L.J., 2008. On the Neogene-Quaternary debate: Episodes, v. 31, pp. 239-242.

Ogg, J.G., 2004. Status of Divisions of the International Geologic Time Scale: Lethaia, v. 37, pp. 183-199.

Partridge, T.C., 1997. The Plio-Pleistocene boundary: Quaternary International, v. 40, pp. 1-100.

Pillans, B., and Naish, T., 2004. Defining the Quaternary: Quaternary Science Reviews, v. 23, pp. 2271-2282.

Remane, J. (Compiler), 2000. International Stratigraphic Chart. International Union of Geological Sciences, and UNESCO Division of Earth Sciences, Paris.

Remane, J., Bassett, M.G., Cowie, J.W., Gohrbandt, K.H., Lane, H.R., Michelsen, O., Wang Naiwen, 1996. Revised guidelines for the establishment of global chronostratigraphic standards by the International Commission on Stratigraphy (ICS): Episodes, v. 19, pp. 77-81.

Salvador, A., ed., 1994. International Stratigraphic Guide, $2^{\text {nd }}$ Edition: The International Union of Geological Sciences and The Geological Society of America, Inc., Boulder, Colorado, pp. i-xix, 1-214.

Van Couvering, J.A., 1997. Preface, The New Pleistocene. pp. ii-xvii. In Van Couvering, J.A. (ed): The Pleistocene Boundary and the Beginning of the Quaternary, Cambridge University Press, Cambridge.

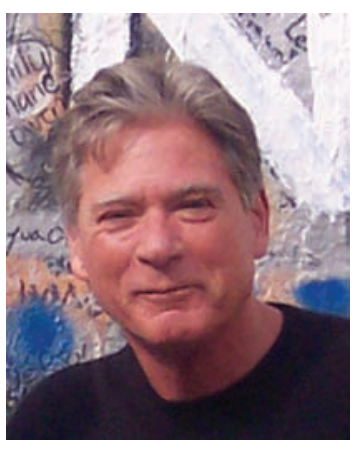

Stan Finney is Professor of Geological Sciences at the California State University at Long Beach, and Chair of the International Commission on Stratigraphy. His research is focused on the biostratigraphy and paleoecology of Ordovician graptolites, the Late Ordovician mass extinction event, the stratigraphy and structure of the Roberts Mountains allochthon in central Nevada, and paleogeographic and geotectonic history of the Argentine Precordillera using detrital zircon geochronology of Neoproterozoic Paleozoic sandstones. 